\section{Hepatitis B among female sex workers in Ribeirão Preto - São Paulo, Brazil}

\author{
Hepatite $B$ entre mulheres \\ profissionais do sexo em Ribeirão \\ Preto - São Paulo, Brasil
}

\section{Abstract}

Objective: To estimate the prevalence of hepatitis B markers and to study the risk factors for this disease among female sex workers in the city of Ribeirão Preto, Brazil. Methods: A questionnaire was given to 449 female sex workers in order to obtain information about demographic, socioeconomic and behavioral variables. Blood samples were collected and analyzed by immunoenzymatic techniques for detection of HBsAg, anti-HBs, anti-HBc and anti-HCV markers. Results: The mean age of participants was 23 years, varying from 13 to 64 years. A high spatial mobility was observed, with $47.9 \%$ of participants residing in places out of the region of Ribeirão Preto or in other Brazilian states. Complete absence of previous vaccine against hepatitis B was referred by $98.2 \%$. Overall, the presence of any hepatitis B marker was observed in 106 participants (prevalence of $23.6 \%$; $95 \%$ CI: $19.7-27.5$ ), with 84 positive for anti-HBs (18.7\%), 100 for anti-HBc (22.3\%), and only 3 for HBsAg ( $0.7 \%)$. The logistic regression analysis showed association between hepatitis B markers and the following co-variables: residence in Ribeirão Preto, age, low socioeconomic level, consumption of crack, intercourse with HIV-infected individuals, history of previous hepatitis, intercourse with a case of hepatitis, and positivity for hepatitis C. Conclusions: Ribeirão Preto's female sex workers present several risk factors for hepatitis B and almost absence of previous specific vaccination, making it necessary to emphasize this low-cost preventive measure, preferably through the use of a mobile team, taking the vaccine to their places of work.

Keywords: Hepatitis B; Prevalence; Sex workers; Prostitutes

Correspondence to: Afonso Dinis Costa Passos. Department of Social Medicine - Ribeirão Medical School - University of São Paulo. Avenida Bandeirantes, 3900 - CEP 14049-900 - Ribeirão Preto, SP, Brazil.Email: apassos@fmrp.usp.br 


\section{Resumo}

Objetivos. Estimar a prevalência de marcadores de hepatite B e estudar os fatores de risco para esta doença entre mulheres profissionais do sexo na cidade de Ribeirão Preto, Brasil. Métodos. Foi aplicado um questionário a 449 mulheres profissionais do sexo, com a finalidade de levantar informações demográficas, socioeconômicas e comportamentais. Amostras de sangue das participantes foram analisadas através de técnicas imunoenzimáticas, para detecção dos marcadores HBsAg, anti-HBs e anti-HBc. Resultados. A idade média das participantes foi 23 anos, variando de 13 a 64 anos. Uma elevada mobilidade espacial foi verificada, com $47,9 \%$ delas residindo em locais fora da região de Ribeirão Preto ou em outros estados brasileiros. Completa ausência de vacinação prévia contra hepatite B foi referida por $98,2 \%$. No total, observou-se presença de qualquer marcador de hepatite $B$ em 106 participantes (prevalência de $\left.23,6 \% ; \mathrm{IC}_{95 \%}: 19,7-27,5\right)$, com 84 positivos para anti-HBs $(18,7 \%), 100$ para anti-HBc $(22,3 \%)$ e apenas 3 para HBsAg $(0,7 \%)$. A análise por regressão logística evidenciou associação entre marcadores de hepatite $\mathrm{B}$ e as seguintes co-variáveis: idade, baixo nível socioeconômico, consumo de crack, relações sexuais com indivíduos infectados pelo HIV, história de hepatite prévia, relações sexuais com pessoas portadoras de hepatite e positividade para hepatite C. Conclusões. As profissionais do sexo em Ribeirão Preto apresentam diversos fatores de risco para hepatite $B$ e quase total ausência de vacinação prévia específica, tornando necessários esforços concentrados na aplicação dessa medida de baixo custo, preferencialmente através do uso de equipes móveis que levem a vacina até os seus locais de trabalho.

Palavras-chave: Hepatite B; Prevalência, Profissionais do Sexo; Prostitutas

\section{Introduction}

The first evidence that hepatitis B can be transmitted by the sex route dates back to the early seventies, with the virus being isolated from saliva, semen ${ }^{1}$ and vaginal secretions ${ }^{2}$, and being frequently detected in patients seen at clinics of sexually transmitted diseases ${ }^{3}$. The hypothesis of sexual transmission eventually gained support from investigations involving persons with intensive exposure, such as sex workers ${ }^{4}$ and male homosexuals ${ }^{5}$. However, the marginalization and discrimination which these groups always suffer caused them to receive little attention from investigators in the health area ${ }^{6}$.

The dissemination of the acquired immunodeficiency syndrome (aids), starting in the 1980's, was a crucial fact for sex workers (SW) to start to be investigated more frequently. Because of the similarity of the mechanisms of transmission and, consequently, of the more vulnerable groups, research on aids indirectly provided information about behavioral and biological aspects related to the transmission of hepatitis B. Although the human immunodeficiency virus (HIV) has a much lower infectivity than the hepatitis B virus $(\mathrm{HBV})^{7}$, it is undeniable that its impact on public opinion and on the academic community is considerably more intense. Because of this, investigations involving SW are directed at aids much more than at hepatitis, impairing the knowledge of the epidemiologic situation of the latter in this high-risk population group.

This clearly occurs in Brazil, where information about hepatitis among SWs is quite scarce. This fact can be observed in Ribeirão Preto, a city of about 500,000 inhabitants located in the Southeast region of the country (State of São Paulo), in which, despite the existence of institutions that support SWs, these workers have never been the target of any epidemiologic investigation regarding health aspects in general, and hepatitis in particular.

The objective of the present study was 
to estimate the prevalence of hepatitis B markers and to study the risk factors for this disease among female SWs working in Ribeirão Preto.

\section{Methods}

With the collaboration of the Municipal Aids Control Program and of the staff of a university institution which provides support to SWs in Ribeirão Preto, the sites where they could be found were identified, as well as their homes and/or places of work. These places were visited by the investigating team, which included a social assistant with extensive experience in work with city SW and a public health physician. The visits to each site were repeated in order to guarantee that all individuals residing or working there could be contacted. When necessary, visits were scheduled in advance in order to facilitate finding and including potential participants. Each site of residence and/or each site for the practice of prostitution identified in the city was visited at least three times in order to guarantee the largest possible number of participants.

Regarding the practice of prostitution in open areas, fixed sites close to the working areas of SWs were first used, with SWs being asked to come to these sites. These activities were complemented with active searches performed on foot or by car, and with the participation of natural leaders identified among potential participants. After this strategy was fully explored, the investigating team started to use an especially adapted bus, which had seats, tables and a large space in the back. This bus allowed for the inclusion of many SW who were reluctant to leave their place of work and to go to a fixed place. Other potential participants were identified and included in the study based on information provided by persons who knew them, using the technique known as snowball sample.

After being informed about the objectives of the investigation, potential participants were given orientation on viral hepa- titis, stressing the modes of transmission and the prostitution-associated risks. According to the status of hepatitis B vaccination, each participant received one dose of the product and a follow-up visit was scheduled for the following doses. After that, they were invited to sign a free term of consent to participate in the study. A questionnaire was then given in order to obtain demographic and socioeconomic data and risk factors for viral hepatitis, with all interviews being conducted by a social worker who had been working with this population for more than five years. At the same time, a $10 \mathrm{ml}$ blood sample was obtained by venous puncture and a serum sample was sent to the National Reference Laboratory of Viral Hepatitis, where they were submitted to immunoenzymatic tests for the detection of the following markers: HBsAg (Hepanostika® HBsAg Uni-Form II - Organon), anti-HBsAg (Biokit@), total anti-HBcAg (Hepanostika ${ }^{\circledR}$ anti-HBc UniForm - Organon), and anti-HCV (UBI HCV EIA® - Organon). Tests were performed and their cut-off points were defined according to manufacturer instructions. Social stratum was defined according to the Brazilian Criterion of Economic Classification used by the National Association of Research Companies ${ }^{8}$. These criteria are based on the following variables: educational level of the head of the family, ownership of some specific household appliances, and presence of a housemaid paid by the participant. Points were attributed to each of these items and the result is expressed in a decreasing numerical classification defining strata: 25 to 34 points (stratum A), 17 to 24 points (stratum B), 11 to 16 points (stratum C), 6 to 10 points (stratum D), and 0 to 5 points (stratum E).

Associations between the qualitative or stratified quantitative variables and the presence of serologic markers for hepatitis B were first determined by the chisquare test. Variables showing a "p" value of 0.25 or less were analyzed by a logistic regression model.

The project was approved by the Medi- 
cal Ethics Committee of Ribeirão Preto's Medical School's Hospital. The data for the study were collected from August 1999 to March 2000.

\section{Results}

As shown in Table 1, the mean age of participants was 23 years, with a wide range (13 to 64 years). The percentage of prostitutes born in the city of Ribeirão Preto and surrounding region was small, with more than $60 \%$ of the subjects originating from other Brazilian states. Less than half of the participants lived in Ribeirão Preto and approximately one third of them maintained a residence in

Table 1 - Social and demographic characteristics of the participants Tabela 1 - Características sociais e demográficas dos participantes

\begin{tabular}{|c|c|c|}
\hline \multicolumn{3}{|l|}{ Characteristic } \\
\hline \multicolumn{3}{|l|}{ Age (years) } \\
\hline mean & \multicolumn{2}{|c|}{23} \\
\hline \multirow[t]{2}{*}{ variation } & \multicolumn{2}{|c|}{$13-64$} \\
\hline & $\mathrm{n}$ & $\%$ \\
\hline \multicolumn{3}{|l|}{ Place of birth } \\
\hline Ribeirão Preto & 28 & 6.2 \\
\hline Rib. Preto region & 37 & 8.3 \\
\hline São Paulo State & 107 & 23.8 \\
\hline Other State & 277 & 61.7 \\
\hline \multicolumn{3}{|l|}{ Place of residence } \\
\hline Ribeirão Preto & 196 & 43.6 \\
\hline Rib. Preto region & 38 & 8.5 \\
\hline São Paulo State & 64 & 14.3 \\
\hline Other State & 151 & 33.6 \\
\hline \multicolumn{3}{|l|}{ Schooling (years) } \\
\hline$<2$ & 28 & 6.2 \\
\hline $2-4$ & 54 & 12.0 \\
\hline $4-8$ & 277 & 61.7 \\
\hline High school & 77 & 17.2 \\
\hline College & 13 & 2.9 \\
\hline \multicolumn{3}{|l|}{ Social category } \\
\hline A & 2 & 0.5 \\
\hline$B$ & 41 & 9.1 \\
\hline $\mathrm{C}$ & 168 & 37.4 \\
\hline $\mathrm{D}$ & 180 & 40.1 \\
\hline $\mathrm{E}$ & 58 & 12.9 \\
\hline Total & 449 & 100.0 \\
\hline
\end{tabular}

other states. There was a predominance of individuals with 4 to 8 years of schooling, followed by those who started or completed high school, whereas $18.2 \%$ had 4 years of schooling or less. The $\mathrm{C}$ and D social strata reached $77.5 \%$ of participants.

A hepatitis B marker was present in 106 SWs, which accounts for a total prevalence of $23.6 \%$ (95\% CI: 19.7 - 27.5). HBsAg was detected in only 3 individuals $(0.7 \%)$, while anti-HBs was present in 84 (18.7\%) and anti-HBc in 100 (22.3\%) participants. A history of previous vaccination against hepatitis B was referred only by 8 SWs, 5 with 1 dose and 3 with two 2 doses.

Logistic regression analysis (Table 2) showed that the variables associated with the presence of hepatitis B markers were: residing in the city of Ribeirão Preto (against those residing out of the town), age (treated as a continuous variable), belonging to lower economic strata $(\mathrm{D}+\mathrm{E}$ as compared with $\mathrm{A}+\mathrm{B}+\mathrm{C}$ ), use of crack, intercourse with anti-HIV-positive partners, previous hepatitis, intercourse with partners with hepatitis, and a positive serological test for the hepatitis $\mathrm{C}$ virus.

\section{Discussion}

Being known to the great majority of SWs and having gained their esteem and respect, the social assistant who held the interviews played the role defined in the literature as a "privileged access interviewer", greatly facilitating the contact and compliance of potential participants ${ }^{9}$. Equally important was the help provided by some SWs, who spontaneously contributed to the recruitment of participants, playing the role of key informers, i.e., individuals from the community, of recognized leadership, and with the potential to influence others to participate or not in the investigation ${ }^{10}$. After repeated visits to all areas in the city where SWs might be encountered, and with a refusal rate of less than $5 \%$, there was reasonable certainty that most SWs had been included, resulting in a number of participants higher than the 
Table 2 - Multivariate association between hepatitis B serological markers and selected features among female sex workers of Ribeirão Preto, Brazil, 2000.

Table 2 - Associação multivariada entre marcadores sorológicos para hepatite B e características selecionadas entre mulheres profissionais do sexo em Ribeirão Preto, Brasil, 2000

\begin{tabular}{lccc}
\hline Variable & OR & Confidence interval (95\%) & $\mathrm{p}$ \\
\hline $\begin{array}{l}\text { Residence in Ribeirão Preto } \\
(1=\text { yes; } 0=\text { no) }\end{array}$ & 1.69 & $1.03-2.78$ & 0.039 \\
$\begin{array}{l}\text { Age* } \\
\text { (continuous) }\end{array}$ & 1.08 & $1.04-1.12$ & 0.000 \\
$\begin{array}{l}\text { Social category } \\
(1=\mathrm{D}+\mathrm{E}) ; 0=\mathrm{A}+\mathrm{B}+\mathrm{C})\end{array}$ & 2.11 & $1.28-3.47$ & 0.033 \\
$\begin{array}{l}\text { Consumption of crack } \\
(1=\text { yes; } 0=\text { no) }\end{array}$ & 4.07 & $2.29-7.23$ & 0.000 \\
$\begin{array}{l}\text { Self-report of sex with an } \\
\text { HIV-positive person }(1=\text { yes; } 0=\text { no) }\end{array}$ & 2.74 & $1.15-6.51$ & 0.023 \\
$\begin{array}{l}\text { Previous hepatitis) } \\
(1=\text { yes; } 0=\text { no) }\end{array}$ & 2.72 & $1.16-6.33$ & 0.021 \\
$\begin{array}{l}\text { Self report of sex with a case of } \\
\text { hepatitis }(1=\text { yes; } 0=\text { no) }\end{array}$ & 2.32 & $1.02-5.31$ & 0.046 \\
$\begin{array}{l}\text { Positive result for hepatitis C } \\
(1=\text { yes; } 0=\text { no) }\end{array}$ & 3.40 & $1.12-10.29$ & 0.030 \\
\hline
\end{tabular}

*increase in risk for every year of life/* ${ }^{*}$ isco aumenta para cada ano de vida

400 initially anticipated by the Municipal Aids Control Program. This fact certainly minimized the possibility of selection biases.

It is interesting to note the power the city of Ribeirão Preto has to attract SWs, as demonstrated by the finding that most of the them were born elsewhere and that more than $1 / 3$ of the prostitutes maintain residence in other states of the country, regularly coming and going for the temporary practice of their activities. This high mobility represents a considerable obstacle to the implementation and maintenance of preventive programs, in addition to allowing the introduction of infectious agents in non-infected areas ${ }^{11}$.

When compared to the population of Ribeirão Preto, participants showed much lower schooling ${ }^{12}$ and, when compared to the Brazilian population as a whole, they showed a higher proportion of individuals belonging to the C and D social strata ${ }^{8}$, demonstrating the low socioeconomic level of the population studied.

Only 6 SWs presented anti-HBs as an isolated serologic marker and among them no one had been vaccinated against hepatitis B. As a consequence, every positive test for this marker can be regarded as result of a previous HBV infection. The possibility of a recall bias was not considered possible, since routine vaccination against hepatitis B started in Brazil only in 1999, covering individuals from birth up to 19 years of age. Considering that data for this investigation were collected from August 1999 to March 2000, it is highly unlikely that a participant would have been vaccinated without remembering it, after such a short period of time.

The prevalence of infection detected among Ribeirão Preto female SWs proved to be lower than those reported in different parts of the world, such as China ${ }^{13}$, Peru $^{14}$, Malaysia ${ }^{15}$, Greece ${ }^{16}$, and Somalia ${ }^{17}$. On the other hand, reduced prevalences similar to those obtained in Ribeirão Preto have been reported in studies conducted in Mexico, in which the possible explanations for the results included the absence of use of illegal injecting drugs, the infrequent practice of anal sex, the use of condoms, and the relative rarity of infec- 
tion in the general population ${ }^{18,19}$. It is possible that some of these factors also contributed to the low occurrence of markers among prostitutes from Ribeirão Preto, where users of illegal injecting drugs were practically non-existent and the use of condoms in commercial sexual relations was generalized ${ }^{11}$.

The finding that residing in Ribeirão Preto is an independent risk factor for hepatitis B is intriguing and has no reasonable explanation since it is not due to differences in age, time of exposure, social stratum or use of drugs, factors that were all controlled for in the logistic regression analysis. Conversely, the strong association with crack consumption is linked to characteristics typical of the use of this drug. Crack tends to be consumed indistinctly by both genders ${ }^{20,21}$ and has a high power to produce severe addiction ${ }^{20,22}$. This condition causes SWs to be vulnerable, being often forced to reduce their prices and to increase the number of clients, in addition to subjecting themselves to highrisk sexual practices demanded by their partners $^{22}$. The percentage of use of this drug was $16.9 \%$ among Ribeirão Preto SWs ${ }^{11}$ and the strong association observed in the present study fully agrees with almost all references in the literature, which are practically unanimous in considering the use of crack as one of the most important predictors of HBV and HIV infection $^{20,22,23}$.

Current or previous use of illegal injecting drugs was reported by only 16 female SWs $(3.5 \%)^{11}$. Although the possibility of false negative responses cannot be completely ruled out, the relationship of acquaintance and familiarity of the interviewer with the participants leads us to believe that, if they occurred, their number was negligible. This finding is in contrast to some reports of high consumption of injecting drugs by SWs at some time in life, with values above $50 \%$ among prostitutes in the United States of America ${ }^{24}$. Since the use of these drugs has been widely recognized as a risk factor for $\mathrm{HBV}$, as well as HIV infection ${ }^{24-26}$, their rare consumption in Ribeirão Preto must have been responsible for the finding of no association in the present study.

The similar mechanisms of HBV and HIV transmission justify the association between self-report of intercourse with an HIV-positive and hepatitis B positive persons. The potential fragility of this information, however, should be recognized, since an occasional sexual partner is generally not aware of the HIV-positive condition of his/her partner.

The association with age must reflect a cumulative effect of behavioral risks and the association with a history of intercourses with hepatitis patients confirms the high potential of HBV for transmission by this route, a fact that has been long $\mathrm{known}^{4,5}$. This may explain, at least in part, the association observed between HBV markers and a previous history of hepatitis.

Underprivileged socioeconomic conditions favor the transmission of $\mathrm{HBV}$ as a consequence of the more frequent adoption of risky sexual practices, such as a lower use of condoms ${ }^{27}$, a longer duration of the workday, and a larger number of partners $^{28}$. Furthermore, socioeconomic difficulties are one of the leading drivers determining the early beginning of prostitution $^{29}$, sometimes defined as survival $s e x^{30}$. In addition, in many cases, prostitutes come from socially maladjusted families in which sexual abuse in childhood and adolescence represents a tragic reality ${ }^{30}$.

Positive serologic results for hepatitis C (HCV) was observed for 17 prostitutes $\left(3.8 \%\right.$ IC $\left._{95 \%}: 2.0-5.6\right)$ with no relation to the use of illegal injecting drugs. The possibility of transmission by the sexual route, in addition to the parenteral route causes simultaneous infection with HBV and HCV to be a predictable event.

The epidemiological findings in this population represent a contribution to the knowledge of hepatitis B among SWs in Ribeirão Preto. Their generalization to other similar cities in the country may be 
possible, but it has to be confirmed by further investigation.

Despite the relatively low prevalence of hepatitis B markers in female SWs in Ribeirão Preto, the presence of several different risk factors ${ }^{11}$, along with the virtual absence of vaccine coverage, confirms the need for implementing intervention measures, based on the massive use of the specific vaccine. Although SWs are eligible to receive this product, it is unrealistic to expect them to visit healthcare units in order to get it. Considering this, one possible approach is to have a mobile team to vaccinate SWs in their places of work, as was the case all along the execution of this investigation. Nevertheless, it must be emphasized that the fight against hepatitis B should also be integrated at the primary health care level, along with AIDS and other STD prevention activities.

We declare no conflict of interest

\section{References}

1. Heathcote J, Cameron CH, Dane DS. Hepatitis B antigen in saliva and semen. Lancet 1974; 1:71-3.

2. Darani M, Gerber M. Hepatitis-B antigen in vaginal secretions. Lancet 1974; 2: 1008.

3. Jeffries DJ, James WH, Jefferiss FJG, MacLeod KG, Willcox RR. Australia (hepatitis-associated) antigen in patients attending a venereal disease clinic. Br Med J 1973; 2: 4556.

4. Papaevangelou G, Trichopoulos D, Kremastinou T, Papoutsakis G. Prevalence of hepatitis B antigen and antibody in prostitutes. Br Med J 1974; 2: 256-8.

5. Szmuness W, Much I, Prince AM, Hoofnagle JH, Cherubin CE, Harley EJ et al. On the role of sexual behavior in the spread of hepatitis B infection. Ann Intern Med 1975; 83: 489-95.

6. Loff B, Gaze B, Fairley C. Prostitution, public health, and human-rights law. Lancet 2000; 356: 1764.

7. Kinsley LA, Rinaldo CR, Lyter DW, Valdisseri RO, Belle $\mathrm{SH}, \mathrm{Ho}$ M. Sexual transmission efficiency of hepatitis B virus and human immunodeficiency virus among homosexual men. JAMA 1990; 264(2): 230-4.

8. Critério de Classificação Econômica Brasil. Associação Nacional de Empresas de Pesquisa. http:// www.anep.org.br/codigosguias/CCEB.pdf (Access in May 2004)

9. Griffiths P, Powis B, Strang J. Reaching hidden populations of drug users by the use of privileged access interviews: methodological and practical issues. Addiction 1993; 88: 1617-26.

10. Watters JK, Biernacki P. Targeted sampling: options for the study of hidden populations. Social Problems 1989; 36(4): 416-30.
11. Passos ADC, Figueiredo JFC. Fatores de risco para doenças sexualmente transmissíveis entre prostitutas e travestis de Ribeirão Preto, Brasil. Rev Panam Salud Publica 2004; 16(2): 95-101.

12. Instituto Brasileiro de Geografia e Estatística. ftp:// ftp.ibge.gov.br/Censos/Censo_Demografico_2000/ educação. Accessed in December 2003.

13. Zhang GQ, Chen SD, Lian JH. Seroepidemiological study of HBV and HCV infection in sexually promiscuous groups. Chung Hua Liu Hsing Ping Hsueh Tsa Chih 1995; 16(4): 213-6.

14. Hyams KC, Phillips IA, Tejada A, Li O, Hermoza P, Lopez $F$, et al. Hepatitis B in a highly active prostitute population: evidence for a low risk of chronic antigenemia. J Infect Dis 1990; 162: 295-8.

15. Ramachandran S, Ngeow YF. The prevalence of sexually transmitted diseases among prostitutes in Malaysia. Genitourin Med 1990; 66(5): 334-6.

16. Tsakris A, Kyriakis KP, Chryssou S, Papoutsakis G. Seroprevalence of hepatitis B markers among females and transsexual sex workers in Athens, Greece. Genitourin Med 1997; 73: 223-4.

17. Jama H, Grillner L, Biberfeld G, Osman S, Isse A, Abdirahman $\mathrm{M}$ et al. Sexually transmitted viral infections in various population groups in Mogadishu, Somalia. Genitourin Med 1987; 63: 329-32.

18. Juárez-Figueroa L, Uribe-Salas F, Conde-Glez C, Hernández-Avila M, Olamemdi-Portugal M, UribeZúñiga $P$, et al. Low prevalence of hepatitis B markers among Mexican female sex workers. Sex Transm Inf 1998; 74(6): 448-50.

19. Hyams KC, Escamilla J, Romero RL, Alvarado EM, Giraldo NB, Papadimos TJ, et al. Hepatitis B infection in a nondrug abusing prostitute population in Mexico. Scand $J$ Infect Dis 1990; 22: 527-31. 
20. Edlin BR, Irwin KL, Faruque S, McCoy CB, Word C, Serrano $Y$, et al. Intersecting epidemics - crack cocaine use and HIV infection among inner-city young adults. $N$ Engl J Med 1994; 331(21): 1422-7.

21. National Institute on Drug Abuse. National household survey on drug abuse: population estimates 1991. Rockville, Md: Department of Health and Human Services; 1991. (DHHS publications no. (ADM) 92-1887)

22. Jones DL, Irwin KL, Inciardi J, Bowser B, Schilling R, Word C, et al. The high-risk sexual practices of cracksmoking sex workers recruited from the streets of three American cities. Sex Transm Dis 1998; 25(4): 187-93.

23. Baseman J, Ross M, Williams M. Sale of sex for drugs and drugs for sex: an economic context of sexual risk behavior for STDs. Sex Transm Dis 1999; 26(8): 444-9.

24. Rosenblum L, Darrow W, Witte J, Cohen J, French J, Gill $\mathrm{SW}$, et al. Sexual practices in the transmission of hepatitis $B$ virus and prevalence of hepatitis delta virus infection in female prostitutes in the United States. JAMA 1992; 267(18): 2477-81.

25. de Carvalho HB, Mesquita F, Massad E, Bueno RC Lopes GT, Ruiz MA, et al. HIV and infections of similar transmission patterns in a drug injectors community of Santos, Brazil. Acquir Immune Defic Syndr Hum Retrovirol 1996; 12(1): 84-92.
26. Guadagnino V, Zimatore G, Izzi A, Caroleo B, Rocca A, Montesano F, et al. Relevance of intravenous cocaine use in relation to prevalence of HIV, hepatitis B and C virus markers among intravenous drug abusers in southern Italy. J Clin Lab Immunol 1995; 47(1): 1-9.

27. Witte SS, El-Bassel N, Wada T, Gray O, Wallace J. Acceptability of female condom use among women exchanging street sex in New York City. Int J STD AIDS 1999; 10(3): 162-8.

28. Lurie P, Fernandes MEL, Hughes V, Arevalo EI, Hudes ES, Reingold A, et al. Socioeconomic status and risk of HIV-1. syphilis and hepatitis B infection among sex workers in São Paulo State, Brazil. AIDS 1995; 9(S1): 31-7.

29. Green ST, Goldberg DJ, Christie PR, Frischer M, Thomson A, Carr SV et al. Female streetworker-prostitutes in Glasgow: a descriptive study of their lifestyle. AIDS Care 1993; 5(3): 321-35.

30. Greene JM, Ennett ST, Ringwalt CL. Prevalence and correlates of survival sex among runaway and homeless youth. Am J Public Health 1999; 89(9): 1406-9.

Recebido em: 01/02/07 Versão final reapresentada em: 11/09/07 Aprovado em: 24/09/07 